\title{
Professional Sunday School Teacher: The Agent Of Building Religious Young Millennial Generation
}

\author{
Prof. Dr. Lince Sihombing, M.Pd \\ \{mutiarafoundation@yahoo.co.id\} \\ Rector of IAKN Tarutung
}

\begin{abstract}
The reason they made are very cliché such as: a). "My goodness, the students already jointhe worship every Monday and Thursday morning". b). The students have conducted their daily worship service every morning at the first session of a class, and c). We must give a chance for IAKN Tarutung students to serve the churches' congregations around IAKN Tarutung. The result of deem trivial attitude done towards the way of managing Sunday school activity cristallizedand revealed through less commendable behaviour of parents, teenagers, students - who previously were Sunday school children' product. The most bare example of less admireable attitudes like this are around, here and there even occurs in IAKN Tarutung. Keywords: Sunday school, millenial generation, professional
\end{abstract}

\section{Introduction}

Almost a year, for many times in the meeting with the functionaries of IAKN Tarutung: Vice to Rector, Deans and Heads of Study Programs I tried my best to encourage them admitting my idea to use the Mini Hall of IAKN Tarutung - as the representation of a church be the place of Sunday worship service for all members of IAKN Tarutung especially for those who are living in IAKN Tarutung's dormitory. But I have always rejected.

The reason they made are very cliché such as: a). "My goodness, the students already jointhe worship every Monday and Thursday morning". b). The students have conducted their daily worship service every morning at the first session of a class, and c). We must give a chance for IAKN Tarutung students to serve the churches' congregations around IAKN Tarutung.

Point c) is the always unreasonable answer they give to me. The main reason of giving such answer is to hide the sorrowful facts ie. if IAKN Tarutung students attend the Sunday worship service at churches around IAKN Tarutung, the practitioners of churches can function them be the teachers of Sunday school children for free of charge. In general, Sunday school teachers are never awarded with the honorarium for every service they do. The young lecturers of IAKN Tarutung always state such a condition as "Thank You Project".

Such condition, is only a bit of facts of how churches existing in Indonesia especially churches in Batak land of North Tapanuli have the very least attention to the Sunday school service and children of this service as well.

Even, the adults who are parents of children of Sunday school service and the church workers - those who are resposible to carry out the church operational duty treat the children of Sunday school as nothing by saying this expression: "Kids, know what?" Therefore, it is enough for them to be taught by on going students of college only, no matter to some extend, these on going students of college could not teach them fully for two months of a semester they are off due to semester holidays. To replace the absence of these college students, the teenagers and parents of church congregation are asked to serve the children of Sunday school. To note, the teenagers who do the teaching, usually are secondary level graduation and parents who do the teaching mostly are house wives with secondary level educational back ground too. It can be understood then that the teaching of Sunday school children are not done professionally since the teachers conducted are not professional too.

The result of deem trivial attitude done towards the way of managing Sunday school activity cristallizedand revealed through less commendable behaviour of parents, teenagers, students - who previously were Sunday school children' product. The most bare example of less admireable attitudes like this are around, here and there even occurs in IAKN Tarutung. 
Out of campus, bad of example can be seen by the attitude of fruit sellers and local product sellers in one of the tourism cities such Lake Toba. The sellers are not afraid of cheating their buyers by showing the weight of a thing such manggoes as $1 \mathrm{~kg}$ while infact the real weight is less than that. The officers of public transportation or travel who serve for Tarutung-Medan round trip or other cities when getting ticket booking over the phone tend to be unfriendly; in IAKN Tarutung campus environment greeting such "Syalom, how are you" is rarely stated by both lecturers and students, the worse, students more often leave the class in worn out condition, the chairs are not in row anymore, garbage and disposal papers and tissue were scattered under the chairs even though the board, announcement such "It is prohibited to move chairs and put trash in its place" are placed right in front of the class or on the doors.

These conditions are in line with the research result conducted by Bambang through Bilangan Research Center entitled "Dinamika Spiritual Generasi Muda Kristen Indonesia" (2018) that students of junior and senior high school attending public school are more ethical than those attending Christian schools. I personally experienced this fact in IT Dell, a public campus at Laguboti on September 9, 2017 when I was invited to attend this IT Dell graduation ceremony. I was repeatedly greeted kindly by the students throughout my journey went around the campus with the kindly greeting: "Good afternoon Ma'am, is there anything I can help you?"

The proverb says "Kecil teranjak-anjak, besar terbawa-bawa" means that all bad traits shown by people mentioned above occur because since their childhood, the religious attitudes such as not to lie, not to damage life environment in various ways such by keeping the class orderly, not to speak rudely, showing emphaty attitude such as: voluntarily help others are almost absence conduted in their life previously. Infact, good manner such as above should be penetrated to them earlier before they reach five years old.

\section{Paradigm Change Of Church Workers On Handling Young Congregation At Sunday School}

Talk about Sunday school certainly is inseparable from the past history. At that time, church congregation during the industrial revolution in 1774, children especially children of marginal people who are not working on Sunday, rather than making a ruckus on the streets, were collected and coached by education sympatism. They were taught by professional teachers in their field and these teachers were given decent salary. What to be taught are complete such as reading, writing, counting, ethics and the like based on Bible. This was inspirated by the thought that Bible provides the basis of education in humanizing the people be the real people

By the time went by, when public schools were opened in 1800s then the task of teaching reading, writing, counting and ethics was taken over by general teachers. What to be taught in church was just about Bible understanding and the teachers were not paid anymore. This was the beginning of decline of Sunday school and handling Sunday school management.

When the Christianity came to Indonesia, the Sunday school teaching pattern is simply the last version that is Sunday school children are not taught by the professionals and the teachers of Sunday school children are not paid.

Church in case of church practitioners forget to handle Sunday school education professionally and paying the honorarium for their service. What to be given attention simply the payroll of church leaders or priests including facilities belong the church. The former District Superintendent (DS) of Gereja Methodist Indonesia said in a joke : "If Sunday school children are given the opportunity and take the opportunity to demonstrate, the first thing they do is to force the Bishop to step back for he has practised continuously this unpopular policy for hundred years".

By seeing and realizing this mistake, it is better for the church leaders within inter and intra denomination to gather together in making paradigm change about handling the young children who arecategorized as Sunday school children. Whenever they want to continue, change, renew the church policy they should consider it holistically and will always allert that whatever a decisionthey make, it will create a wave of protest and annoyance. However the change should be made if the church leaders are not ready to face the frighten problems as it has been explained before - emerge continuously. 
The church leaders should be aware that the performance of church includes two things at once at the same time i.e. the construction of the church are physically and non physically. The construction of a church physically is no doubt. It can be seen in pockets of christianity of North Tapanuli. From one denomination of a church - stands within $6 \mathrm{~km}$. If it is combined with the church of other denominations then the ratio can be per $4 \mathrm{~km}$ stands one church.

The construction of the church building in non physical, the church congregation mainly young age who are categorized as Sunday school classes, should also be given the same treatment. It does not mean to patronize the church leaders that it is better to reduce the portion of the church building and then redirected to the building of non physical i.e. Sunday school children management who infact the asset of the church at the same time contributing towards the country's assets in form of work force in the future.

Ideally the church is also managed the same as managing educational institutions because the church is indeed the education place where the emphasis is religious side of christianity and christian people as well. If this is handled seriously like handling the education world, so it is necessary for the church to have a master plan of development (RIP), strategic plan (Renstra) as well as the operational plan (Renop) annually even designing long term plan (RJP) per 5 of the year.

At any given moment when annual meeting is conducted, mapping of road map product performance as physical and non physical place is done. The idea is believed will create the pros and cons as it will change the concrete order which have been made massively from time to time since the exposure to RIP, Renstra, Renop done thoroughly and cover the entire Indonesia so the advice - based on local wisdom from the representatives of church will color the decision making and their implementation in the territories with varied cultural background conditions. With this condition it can be understood why our neighbour can conceived the idea of an Islam Nusantara.

On this occasion the knowledge of the participants of the annual meeting who have back ground of sociology of religion can contributed significantly about the need to reviewing various aspects holistically and to be able to decide the new policy about the art of handling the Sunday school children professionallyespecially about the art of handling the Sunday school children.

\section{Participation of Religion Education Institutions In Preparing Professional Sunday School Teachers}

Commonly, religion institution such as IAKN, STAKN/STAKPN which belongs to Indonesia government and private STT which built for the shake of church or the public have contributed for the in put of the church workers. However the participations are not so significantsince the graduation that can be used bychurches simply the theological graduation whereas the graduation of Christian religion education (PAK) and church musical education (PMG) are used by general public schools where the students are thye blended of students who come frrom different religionbackgrounds.

Pastoral Counseling graduates who speak and work based on soul healing have thus turn out to be used by the industrialized world (DUDI), social centres such as hospitals, nursing homes and psychiatrics clinics. This year IAKN Tarutung educates students of PAUD but even though there is a Christian label attached on the status of future graduates, their users are public schools in which have students come from different religion background.

If point two of this material can be realized then IAKN Tarutung will open a new studyprogram i.e. Dikdas (primary education) and Sunday school children education (PASM). Graduates of Dikdas study program will also include the teachers who will teach in Sunday school (PASM) for Sunday school children are from above 5 years old. The existance of this Dikdas is crucial since religion subject now is treated as one of subjects of national examination.

If possible, there must be government involvement in managing this two different institutions school and church through curriculum development and curriculum application, the formalization of the status of Sunday school teacher such the government treat well teachers of PAUD and Dikdas.

Religion studies at school that handled down by these religion teachers are believed giving insufficient result because besides students to be handled down in a class are in a big number, the religion teachers are also obliged to teach for 24 hours per a week. It makes PAKteachers do not teach maximum. Lack of attention given by this PAK teachers will be covered by teachers graduate from Dikdas through the study program of Sunday school children education (PASM).. 
Specifically for study program of Sunday school children education (PASM), studentswho are trained around four years are given a chance to accommodate the interest of Sunday school children because the concept of education contained in the RIP, Renstra and Renop gives them the opportunity to do so.

\section{Conclussion}

Based on all explanation discussed above it can be concluded that:

1. There must be changing paradigm of top leaders of churches in treating the teachers of Sunday school children. When priests of congregation are the product of formal education, to make them professional enough, the same thing should be done upon the teachers of Sunday school children.

2. Christian institution such as IAKN, STT provides the new study program for this Sunday school teacher.

3. If possible, there must be government involvement in managing this two different institution: school and church through curriculum development and curriculum application and the formalization of the status of Sunday school teacher such the government treat well teachers of PAUD and Dikdas. 